\title{
Effect of Moisture content on the drying rate using traditional open sun and shade drying of fish from Njuwa Lake in North- Eastern Nigeria
}

\author{
U. U. Modibbo $^{* 1}$, S.A. Osemeahon ${ }^{1}$ and M. H. Shagal ${ }^{1}$, M. Halilu ${ }^{2}$ \\ ${ }^{1}$ Department of Chemistry, Modibbo Adama University of Technology Yola, P.M.B 2076 Yola, Nigeria \\ ${ }^{2}$ Department of Food Science, Modibbo Adama University of Technology Yola, P.M.B 2076 Yola, Nigeria
}

\begin{abstract}
In this study, fish samples namely, Tilapia zilli, Clarias geriepinus, Synodontis ocellifer and Alestes baremose were obtained from Njuwa Lake, Yola Adamawa State. Moisture content and other proximate composition was analyzed using methods of open sun drying $\left(40-42^{\circ} \mathrm{c}\right)$ and shade drying $30-32^{\circ} \mathrm{c}$ respectively. Results showed that the values reported for moisture, crude fibre, crude lipid, crude protein, ash and carbohydrate were ranged between 4.72-7.63, 3.02 $\pm 0.23,7.13 \pm 0.23,59.26 \pm 0.35,1.61 \pm 0.01$ and 0.3 for Tilapia zilli, while values of 4.39-8.21, $2.61 \pm 0.06,7.24 \pm 0.06,64.32 \pm 1.25,1.86 \pm 0.03$ and 0.08 are for dried Clarias geriepinus respectively. Also values of Synodontis ocellifer were 3.90-7.10, $3.62 \pm 0.05,6.52 \pm$ $0.13,55.99 \pm 0.33,0.99 \pm 0.01$ and 0.1 respectively. While values of 4.41-7.32, $2.91 \pm 0.04,8.23 \pm 0.05,55.31$ $\pm 0.25,1.96 \pm 0.04$ and 0.2 are for Alestes baremose fish species. Moisture content observed is as follows: Clarias geriepinus > Tilapia zilli > Alestes baremose > Synodontis ocellifer.

Key words: Fish, moisture, open sun drying, shade drying, Tilapia zilli
\end{abstract}

\section{Introduction}

Fishes form one of the most important groups of vertebrates for man, influencing his life in various ways. Millions of human beings suffer due to hunger and malnutrition, and fishes form a rich source of food and provide a means to tide over the nutritional difficulties of man. Fish flesh contains up $15-25 \%$ protein, $80 \%$ water, $1-2 \%$ minerals matter $[1,2]$ reported that, fish is a highly perishable food materials because of its high moisture and nutrient contents and spoilage begins as soon as fish dies. It has also been reported by [3] that immediately the fish dies, a number of physiological and microbial deteriorations set in and thereby degrade the fish. The relative high moisture content and high degree of unsaturated fatty acids in fish accounts for its perishability either during processing or storage [4]. Therefore, there is need for sun drying method by this; preservation is achieved by lowering water content in fish, thereby retarding activity of bacteria and fungi [5]. Drying or dehydration removes active water and stops microorganism growth. It also reduces rate of enzymes activity and chemical reactions. While drying, there is moisture loss, and fish protein and other substances tend to be concentrated and product becomes hard [6]. During drying moisture content and water activity are reduced and hence microorganisms cannot grow and multiply to spoil fish. This will help in preserving fish for a long time [7].

Simple sun-drying is the widely practiced traditional method of fish preservation and that sun drying depends heavily on the natural weather, since the fish dries by heat from sun and the air current carries water away. Rack drying has been used as the most hygienic method for sun-drying. Here fishes are dried on raised racks above ground. This can be made by tying old webbings to poles made of locally available materials, which are fixed at fixed distances from each other, this ensures circulation of air from both top and bottom, and contamination of the product with sand or dust is almost avoided and quality product is assured. Here, racks can be sloping type where there is a drain of water, or it can be multi-deck racks that consist of two layers or more [2]. Because the importance of fish drying is growing among all classes of consumers that some are consumed inside the country and a smaller portion is exported.

The objective of the present work was to study the effect of open sun-drying and shade drying on some fish species from Njuwa Lake, and to assess the moisture loss of the different fish samples in Lake Njuwa based on the expected standard set by the public health department [8].

\section{Materials And Methods Study Area}

Njuwa lake is located in Rugange village of Yola South Local government Area, Adamawa State. It lies between lattitude $8^{0} \mathrm{~N}$ and $11^{0} \mathrm{~N}$, and longitude $11.5^{\circ} \mathrm{E}$ and $13.5^{\circ} \mathrm{E}$. It is a small lake of $\left(2.8 \mathrm{~km}^{2}\right.$, shallow (average depth $3 \mathrm{~m}$; maximum depth $5 \mathrm{~m}$ ). It was formed naturally and specifically used for annual fishing festival during the months of March annually for duration of two days and for farming irrigation. 


\section{Sampling process}

Four samples (Tilapia zilli, Clarias gariepinus, Synodontis ocellifer and Alestes baremose) were used for the analysis of the moisture content using open-sun drying and shade drying methods respectively. The aforementioned fish were caught from Njuwa Lake. The fish samples were cleaned and gutted. Fish sample was cut and prepared for drying. The samples were then dried under the open-sun and shade and moisture content for each sample were measured at interval of 30 minutes each, until equilibrium is maintained.

\section{Analytical Process}

Determination of Moisture Content: open sun and shade drying methods was used in the determination of moisture content. $11.87 \mathrm{~g}$ of fresh fish samples were weighed at the initial of the experiment and the drying temperatures of the aforementioned methods of the time of conducting the experiment are at $\left(40-42^{\circ} \mathrm{C}\right)$ and $(30$ $-32^{\circ} \mathrm{C}$ ) respectively. The measured samples were placed until a constant weight for $7 \mathrm{~h}$ and $30 \mathrm{~min}$ was obtained according to the official methods of analysis [9]. The percentage moisture content (\% MC) was computed as follows:

Moisture $(\%)=$ Loss in weight on drying (g) / Initial sample weight X 100

Determination of Ash Content: The standard test method for ash content-ASTM D2866-94 was used. A crucible was pre-heated in muffler furnace to about $500^{\circ} \mathrm{C}$ for 3 hours. It was then cooled in desiccators and weighed. $1.0 \mathrm{~g}$ of each dried fish sample was transferred into the crucibles and re weighed. The crucibles containing the samples were then placed in a cold muffler furnace and the temperature was allowed to rise to $500^{\circ} \mathrm{C}$. It was removed and allowed to cool in a desiccator to room temperature $\left(30^{\circ} \mathrm{C}\right)$ and re weighed again. The ash content was calculated using the equation: Ash $(\%)=$ ash weight $(\mathrm{g}) / \mathrm{O}$ ven dry weight $(\mathrm{g}) \mathrm{X}$ 100

Determination of Crude Fiber: $1.0 \mathrm{~g}$ of each fish sample was boiled in $30 \mathrm{ml}$ of $0.3 \mathrm{~N}$ sulphuric acid for 15 minutes, then $40 \mathrm{mls}$ of $1.5 \mathrm{~N}$ sodium hydroxide was added, the boiling was continued for another 15 minutes and then allowed to cool. The mixture was then filtered and washed several times with distilled water. The residue was then treated with $0.3 \mathrm{~N}$ hydrochloric acid, filtered and washed with distilled water to neutrality and then with acetone. The residue was then dried in an oven at $105^{\circ} \mathrm{C}$ then weighed into a clean crucible and ash for 3 hours at $500^{\circ} \mathrm{C}$. Crude fibre was calculated using the equation:

Crude fibre (\%) weight of sample before using - weight of sample after using / weight of sample after using $\mathrm{X}$ 100

Determination of crude Lipid (Ether Extract): $2 \mathrm{~g}$ of the sample for each fish sample was weighed into a 250 $\mathrm{ml}$ conical flask and $50 \mathrm{ml}$ of diethyl ether was added, shook and allowed to stand overnight. The mixture was then filtered over a gravity filtration set and washed down with the same solvent. The ether was removed by evaporation on a water bath and then dried at $105^{\circ} \mathrm{C}$ in the oven for 1 hour and weighed. Percentage oil was calculated using the equation

Crude Lipid (\%) = weight of oil / weight of sample X 100

Determination of crude protein and carbohydrate was carried out according to the official methods of analysis [9].

\section{Results And Discussion}

Table 1: Moisture Content for open-sun and shade-drying at varied temperature of $40-42^{\circ} \mathrm{c}$ and $30-32^{\circ} \mathrm{c}$ respectively

\begin{tabular}{llccc}
\hline Fish Sample & Drying method & Initial weight(g) & Final weight (g) & \% Moisture \\
Tilapia zilli & F-OS/drying & 11.17 & 4.72 & 42 \\
& F-S/drying & 11.17 & 6.85 & 51 \\
& H-OS/drying & 11.17 & 6.51 & 68 \\
& H-S/drying & 11.17 & 7.63 & 42 \\
Clarias geriepinus & F-OS/drying & 11.17 & 4.65 & 59 \\
& F-S/drying & 11.17 & 6.61 & 39 \\
\hline
\end{tabular}




\begin{tabular}{lllll} 
& H-S/drying & 11.17 & 8.21 & 74 \\
Synodontis ocellifer & F-OS/drying & 11.17 & 4.23 & 38 \\
& F-S/drying & 11.17 & 6.04 & 54 \\
& H-OS/drying & 11.17 & 3.90 & 35 \\
Alestes baremose & 11.17 & 7.10 & 64 \\
& H-S/drying & 11.17 & 4.79 & 43 \\
& F-OS/drying & 11.17 & 6.34 & 57 \\
& F-S/drying & 11.17 & 4.41 & 39 \\
& H-OS/drying & 11.17 & 7.32 & 66 \\
\hline
\end{tabular}

Key: F-OS, flesh open sun; F-S, flesh shade; H-OS, head open sun; H-S, head shade.

Table 2: proximate composition of fish ${ }^{\mathrm{a}}$

\begin{tabular}{llccccc}
\hline Fish sample & $\begin{array}{l}\text { Moisture } \\
\text { content (range) }\end{array}$ & Crude fiber & Crude Lipid & Crude protein & Ash & $\begin{array}{c}\text { Carbohydrate } \\
\text { (without fiber) }\end{array}$ \\
\hline Tilapia zilli & $4.72-7.63$ & $3.02 \pm 0.03$ & $7.13 \pm 0.23$ & $59.26 \pm 0.35$ & $1.61 \pm 0.01$ & 0.3 \\
Clarias geriepinus & $4.39-8.21$ & $2.61 \pm 0.06$ & $7.24 \pm 0.06$ & $64.32 \pm 1.25$ & $1.86 \pm 0.03$ & 0.08 \\
Synodontis ocellifer & $3.90-7.10$ & $3.62 \pm 0.05$ & $6.52 \pm 9.13$ & $55.99 \pm 0.033$ & $0.99 \pm 0.01$ & 001 \\
Alestes baremose & $4.41-7.32$ & $2.91 \pm 0.04$ & $8.23 \pm 0.05$ & $55.31 \pm 0.25$ & $1.96 \pm 0.04$ & 0.2 \\
\hline
\end{tabular}

${ }^{\text {a }}$ Values are means of triplicate determination+ SD

From Table 2. It was observed that the moisture content has decreased from initial moisture content (M.C.) of 11.17 to a range of between 3.90 to 4.72 as depicted in Table 2. Due to the reduction in moisture content, it was observed that the crude protein, crude lipid and ash all increased. This low moisture content is an indication that the dried fish samples have a tendency to be very stable. This results is in agreement by the work conducted by [3]

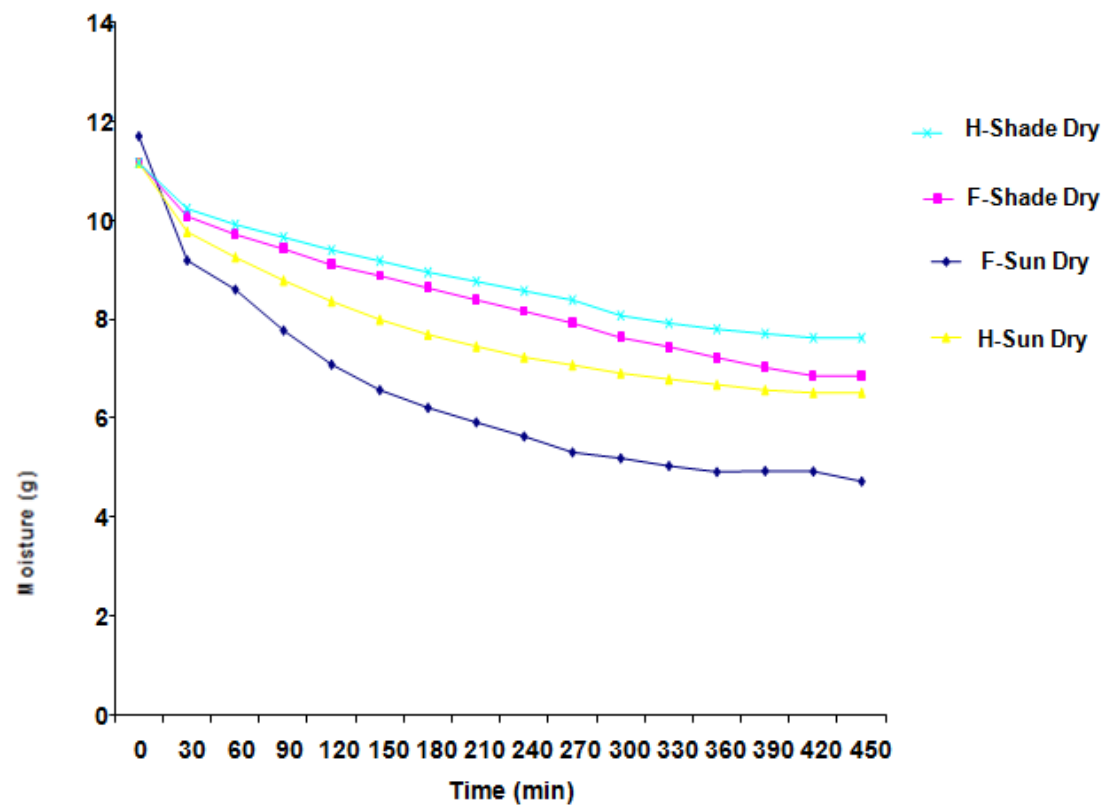

Fig 1: variation moisture content of Tilapia zilli with time in minutes 
Figure one shows the variation moisture content of Tilapia zilli fish for open-sun and shade drying in minutes. The result of this data was compared of fish samples dried under the open-sun and the shade.

The initial moisture content was $11.17 \mathrm{~g}$ for flesh sample and $11.17 \mathrm{~g}$ for head sample as shown in figure 1 above. The moisture content decreased from $11.17 \mathrm{~g}$ to 4.72 after 7:30 hours of sun drying but when compared with the fresh head sample under the sun for 7:30 hours, result obtained showed that the moisture content decreased from $11.17 \mathrm{~g}$ to $6.51 \mathrm{~g}$, and this shows that the heat radiation penetration required to dry the head sample was more as compared to the flesh sample. The decline in moisture content was greatest in flesh sample than in the head sample which dried slowly. This indicates that the head sample had more moisture.

This result was compared to the shade drying sample, result reveals that drying was slower under the shade than in the sun for both samples that is flesh sample dried for 7:30 hours under the shade was $11.17 \mathrm{~g}$ to $6.85 \mathrm{~g}$ and head sample dried for the same period of time showed a moisture content decrease from $11.17 \mathrm{~g}$ to $7.63 \mathrm{~g}$. these results portrays that drying fish sample under the sun is faster than in the shade [2] shows that, diffusion will increase with rise in temperature. Drying will therefore proceed more rapidly with temperature increase.

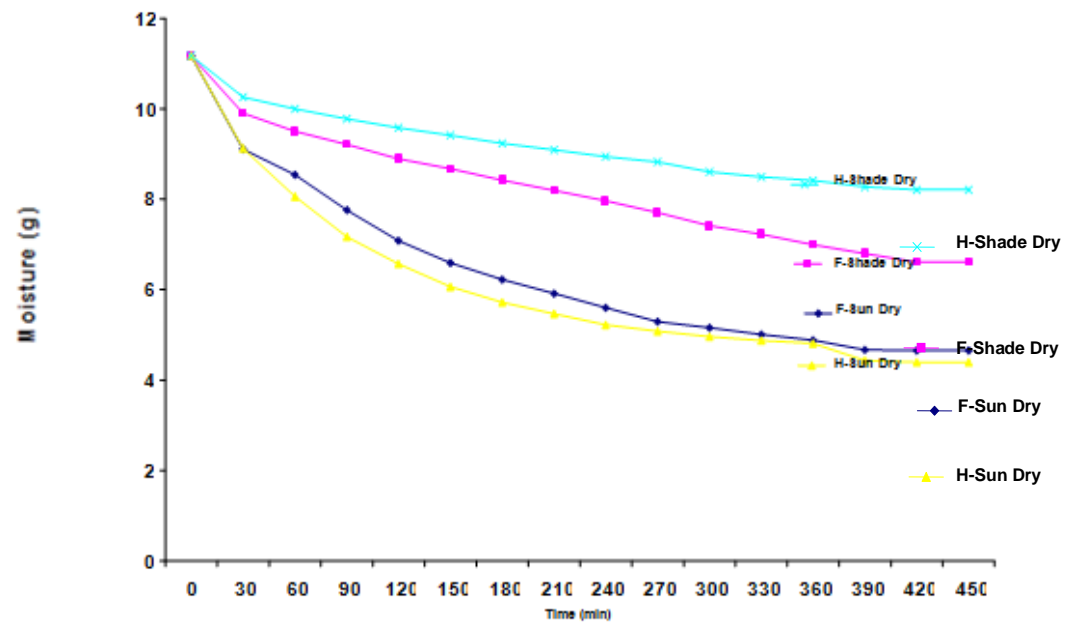

Fig 2: variation of moisture content Clarias geriepinus with time in minutes.

In figure 2 shows variation of moisture content between the dehydrated fish samples under the sun and shade drying. It is evident in the result that there was a clear variation. Fish sample dried under the open-sun and head sample dried under the shade, portrays the following result under the same temperature. For flesh sample $11.17 \mathrm{~g}$ was reduced to $4.65 \mathrm{~g}$ and the head sample the moisture content was reduced from $11.17 \mathrm{~g}$ to $4.39 \mathrm{~g}$, comparing the results of sun drying and shade drying from an initial weight $11.17 \mathrm{~h}$ the result shows that flesh sample was reduced to $6.61 \mathrm{~g}$ and 8.21 respectively. This indicated that sample dried under the sun is faster. Considering the use of drying and shade drying it has been observed that the sun drying take period of dehydration of fish sample $[10,11,12]$.

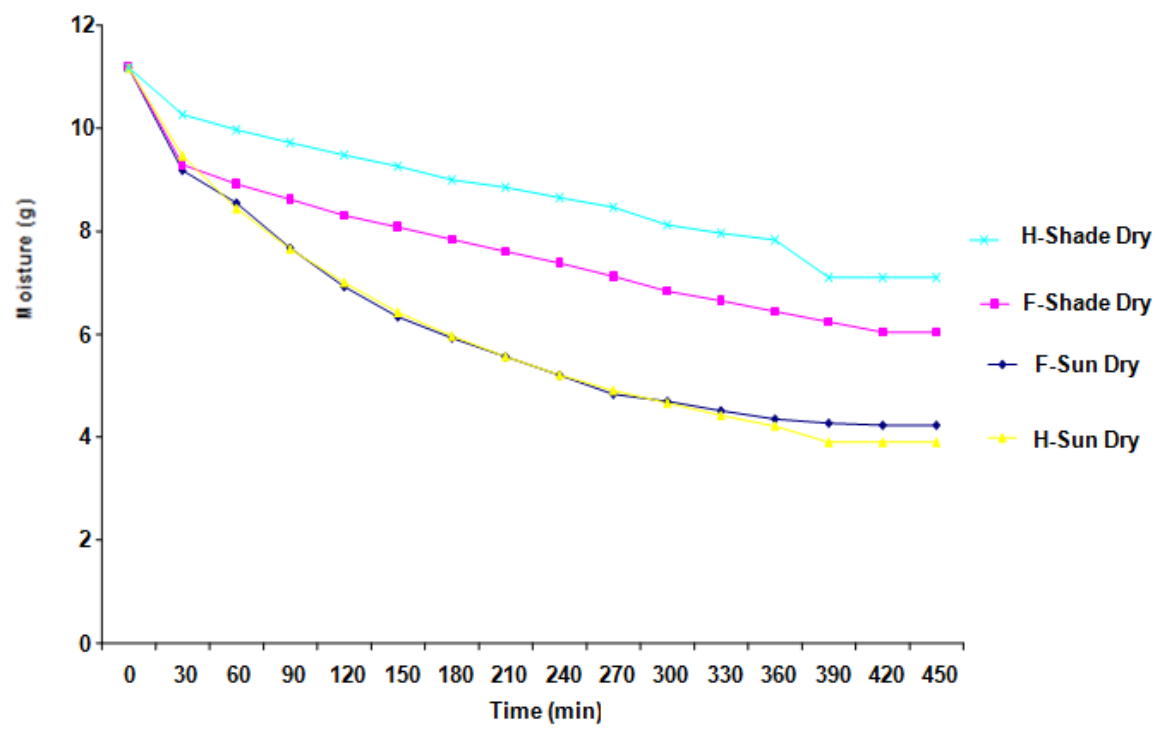

Fig 3: variation of Moisture Content of Synodontis ocellifer with time in minutes.

Figure 3 shows changes in moisture content of Synodontis ocellifer for sample dried under the sun and in the shade temperatures. From the result it was observed that, flesh sample for both sun and shade drying and head 
sample for sun drying had a linear decrease in moisture content from $11.17 \mathrm{~g}$ to $8.6 \mathrm{~g}$ as compared to head sample for shade drying with a decrease in moisture content from an initial $11.17 \mathrm{~g}$ to $10.2 \mathrm{~g}$. it was also observed that flesh and head samples which was dried under the same temperature had the same pattern of moisture decrease (fig 3). Though at time 330 minutes there was a slight difference in moisture decrease observed between the two samples.

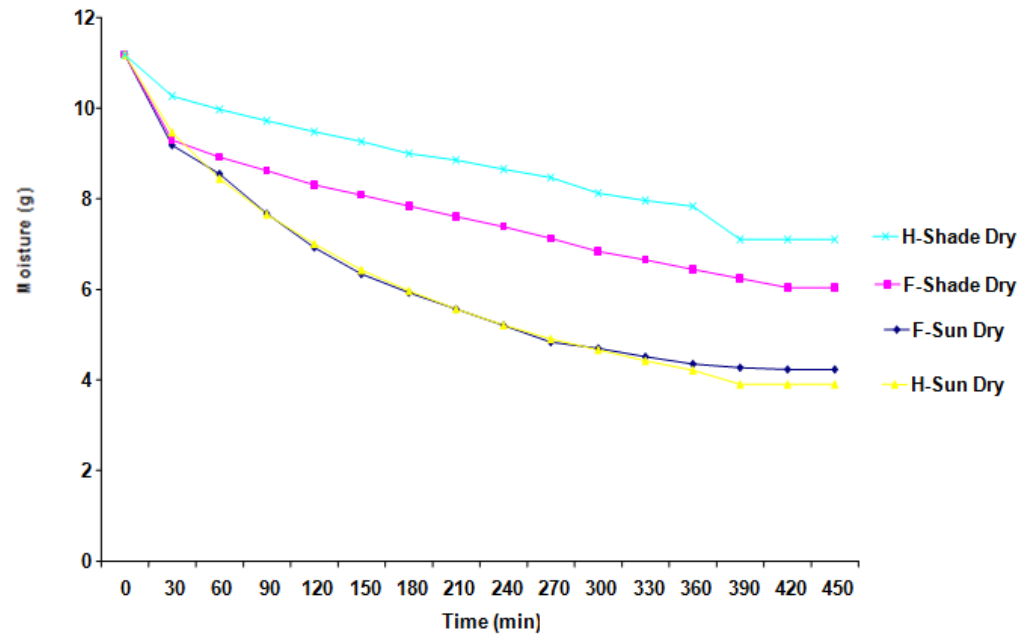

Fig 4: variation of Moisture content of Alestes baremose fish for sun drying and night with time in minutes.

Figure 4 shows the moisture content between the fish dried in the open-sun and in the shade drying respectively. It is evident from the results show in figure 4 that variation of moisture content was different due to two clear reasons. One reason is the difference in the use of open-sun drying and drying of fish in the shade. The second reason is the size differences of the fish species. Flesh and head sample dried under the open sand which indicated the following results for flesh samples, the initial weight was $11.17 \mathrm{~g}$ and was reduced to $4.7 \mathrm{~g}$ and the head sample the moisture content was reduced from $11.17 \mathrm{~g}$ to $4.49 \mathrm{~g}$ respectively.

The moisture content of flesh dried under shade decreased from $11.7 \mathrm{~g}$ to $6.5 \mathrm{~g}$ followed by head dried under same shade also decreased from 11.17 to $8 \mathrm{~g}$ respectively. Therefore, the declined in moisture content was greatest in open-sun drying while that of shade-dried samples showed lower drying rate constants.

\section{Conclusion}

This study shows that sun drying is a viable method of producing a good quality dried fish. Open sun and shade drying achieved by simply exposing the fish sample to the sun is a fast and easy method which gives a product of acceptable quality, with an efficient drying process for fish preservation.

\section{References}

[1]. American Public Health Association (APHA). Compendium of methods for the microbiological examination of foods, $3^{\text {rd }}$ edition 1992.

[2]. Ayyappan S., Jena K., Gopalakrishman A. and Pandey K. Hand book of Fisheries and Aquaculture. Indian Council of Agricultural Research New Delhi, 2006.

[3]. Gamal F. Mohammed, Eman M. Hegazy and M. Abdullatef. Physicochemical Properties and Mycotoxins contents of Tilapia fishfillets after Solar Drying and Storage. Volume 7 (2) 2011, 138-148

[4]. Shaidi F. Fundamental seafood lipids and proteins, I: foundational foods. Biochemical and processing aspects G. Mazza (ritsts), Tachometric puploling, Lancaster,1998, 381-401

[5]. Pomeranz Y, and Meloan C. Food analysis; theory and practice, $2^{\text {nd }}$ Edition. Van Nostrand Reinhold, New York, NY, 1987.

[6]. Aurand L.W., Woods, A. E and wells, M.R. Food composition and Analysis. Van Nostrand Reinhold, New York, NY, 1987.

[7]. Sabina S, Selina P, and M. Altaf Hossain. Biochemical Analysis of some dried Sis Fishes of the river Padama in Rajshahai. J. life Earth Sci., Vol. 6: 2011, 39-43.

[8]. Wahed M. A and Khaleque M.A. Fisheries industrial visit report, IFST, BCSIR, Dhaka, 2001

[9]. A.O.A.C. International official methods of analysis $20^{\text {th }}$ Edition. Gaithersburg, MD, USA, 2007.

[10]. Doe P.E., Ahmed M., Muslemuddin M and K Sachithanan than. Apolythene Ten Dryer for improved sun drying of fish. Food Technology in Australia Vol. 29 (II), 1977, 437 - 441

[11]. Shahunthala, D. Heavy metals levels in Malaysian fish. Fisheries. Bulletin 44 (1989).

[12[. Titus H. T. "Comparative Analysis of trace Heavy metals Along the River Benue Bank from Jimeta Bridge to Gerio in Yola, Adamawa, Nigeira. M. Tech Thesis, Department of Chemistry. Federal University of Technology, Yola, Nigeria, 2003. 15-16. 